\title{
STUDI FENOMENA MENJEMUR PAKAIAN YANG MEMBENTUK CITRA KURANG BAIK BANGUNAN RUMAH SUSUN Studi Kasus: Rumah Susun Sarijadi, Kota Bandung
}

\author{
Nurul Sucya Karya \\ Program Studi Magister Arsitektur, SAPPK, Institut Teknologi Bandung \\ Jl. B, Lb. Siliwangi, Kecamatan Coblong, Kota Bandung \\ *Email: nurulsucyakarya@gmail.com
}

\begin{abstract}
Menjemur is literally means drying laundry by hanging them to be exposed by the sun or open air. In Indonesia, misplaced menjemur phenomenon is frequently seen in low-cost apartment, which is giving a bad image to the building. By choosing the case of low-cost apartment (Rumah Susun) in Sarijadi Bandung, this small research tried to dig deeper towards misplaced menjemur phenomenon in Rumah Susun. The data collection method used for this small research is field observation and interview to the Rumah Susun occupants, which are then being analyzed descriptively. It can be seen that the Rumah Susun occupants improperly place their laundry to be dried, such as in balconies, corridors, stairs, and windows. This thing happened because there isn't any facility to place their laundry in Rumah Susun provided. Moreover, this phenomenon shows that the occupants don't have any other choice towards their settlement, which is called "bounded choice", as the result of Rumah Susun building programme orientation which is done by top-down method that produce a nearly uniformed building form. This bounded choice phenomenon could harm the Rumah Susun image, and in long term could reduce the occupants interest to live in Rumah Susun. An occupant behaviour-based improvement towards the Rumah Susun building programme is needed in the future, to produce a Rumah Susun form which has a good image. The outcome of this research could be a material to evaluate the Rumah Susun building design.
\end{abstract}

Keywords: Drying Laundry, Rumah Susun Sarijadi Bandung City, Bounded Coice.

\section{PENDAHULUAN}

Pembangunan rumah susun (rusun) di Indonesia diawali sekitar tahun 70-80 an. Berdasarkan UU No. 20 Tahun 2011 pasal 1, Rumah susun adalah bangunan gedung bertingkat yang dibangun dalam suatu lingkungan yang terbagi dalam bagian-bagian yang distrukturkan secara fungsional, baik dalam arah horizontal maupun vertikal dan merupakan satuan-satuan yang masing-masing dapat dimiliki dan digunakan secara terpisah, terutama untuk tempat hunian yang dilengkapi dengan bagian bersama, benda bersama dan tanah bersama.

Pembangunan rusun di Indonesia yang bersifat top-down ini banyak dibangun dengan teori-teori hunian vertikal dengan tipologinya yang sudah ada, sehingga banyak ditemukannya hunian-hunian vertikal yang nyaris sama satu dengan lainnya "seragam". Selama ini pembangunan rusun di Indonesia hanya terkonsentrasi pada kebutuhan ruang bagi penghuninya saja, tetapi aspek perilaku atau aktifitas yang terjadi di permukiman sebelumnya kurang diperhatikan. Oleh karena pembangunan rusun yang hanya berlandaskan pada teori-teori hunian vertikal tersebut, aspek seperti keadaan sosial, budaya dan ekonomi warga menjadi kurang diperhatikan.

Oleh karena kurang diperhatikannya aspek utilitas bangunan (pengaturan ruang yang baik didasarkan pada fungsi, dll) sehingga banyak fungsi ruang-ruang pada rusun yang digunakan tidak sebagaimana fungsinya, yang semestinya mengacu pada teori arsitektur modern bahwa bentuk mengikuti fungsi (form follow function), tetapi yang terjadi adalah bentuk yang memicu fungsi tertentu. Seperti terlihat fenomena menjemur pakaian yang tidak pada tempatnya di banyak rusun di Indonesia.

Dari adanya fenomena menjemur pakaian yang tidak pada tempatnya di banyak rusun di Indonesia, memberi kesan/citra kurang baik 
pada bangunannya, bangunan terlihat tidak tertata dan terkesan kumuh. Menurut Romo Mangun di dalam bukunya Wastu Citra: 31 (1988), Citra sebetulnya hanya menunjuk suatu "gambaran" (image), suatu kesan penghayatan yang menangkap arti bagi seseorang. Citra tidak jauh sekali dari guna, tetapi lebih bertingkat spiritual, lebih menyangkut derajat dan martabat manusia yang menghuni bangunannya. Citra menunjuk pada tingkat kebudayaan, sedangkan Guna lebih menuding pada segi keterampilan/kemampuan.

Dari peninjauan penulis terhadap objek studi yang diambil, yaitu rusun Sarijadi Bandung, terdapat dugaaan terjadinya "Bounded Choice" (pilihan non optimum) pada penghuni. Kondisi dimana penghuni bersikap puas pada kondisi faktual yang minim/rendah (satisfaction with low quality).

\section{METODE PENELITIAN}

Penelitian ini menggunakan metode kualitatif (Creswell, 2008) yang bersifat narratif study (deskripsi fakta) dan case study (mengungkap kasus). Metode pengumpulan data yang akan dilakukan adalah observasi lapangan serta wawancara (unstructure interview) dengan penghuni rusun dan masyarakat yang tinggal di sekitar rusun sarijadi, untuk kemudian dilakukan analisis perseptual yang bersifat deskriptif. Pemilihan sampling yaitu memilih penghuni yang dinilai cukup memiliki pengaruh dan telah lama tinggal di rusun tersebut (purpose sampling). Responden yang dipilih adalah Ibu Ujang, Ketua RT setempat yang tinggal di rusun Sarijadi sejak tahun 1985 dan Ibu Liun, masyarakat yang tinggal di sekitar rusun sarijadi. Dilakukan dengan analisis perseptual yang bersifat deskriptif mengenai kondisi huniannya.

\section{Metode Analisis: Analisis Perseptual}

Disini penghuni rusun sebagai pengamat, akan memberi kesan berupa penilaian mengenai kondisi huniannya. Ketika lingkungan terbentuk, manusia sebagai pengamat mulai melakukan pengenalan terhadap lingkungannya melalui pancaindera/ pengalaman fisik dan pengalaman psikis. Proses input pengalaman terhadap lingkungan tersebut merupakan pemetaan kesadaran (kognitif) yang dilakukan oleh penghuni sebagai pengamat.
Pemetaan kognitif dapat dijadikan alat untuk mengetahui citra/image dari suatu lingkungan, dengan menanyakan kondisi hunian dengan opini pengamat melalui petakognitif. Kesan - kesan yang dinyatakan oleh penghuni dapat menjadi kriteria dalam penilaian citra lingkungan huniannya. Oleh itu pada studi inia kan ditanyakan persepsi penghuni terhadap kondisi huniannya.

\section{Objek Studi}

Rusun Sarijadi terletak di Jl. Sarijadi blok D no.1, Sarijadi Kota Bandung. Di bangun sekitar tahun 1980 an, terdiri dari 16 blok (Blok D-S), 1 blok terdiri dari 2 tower yang 1 towernya terdiri dari 32 unit, sehingga 1 blok terdiri dari 64 unit (Gambar 1).

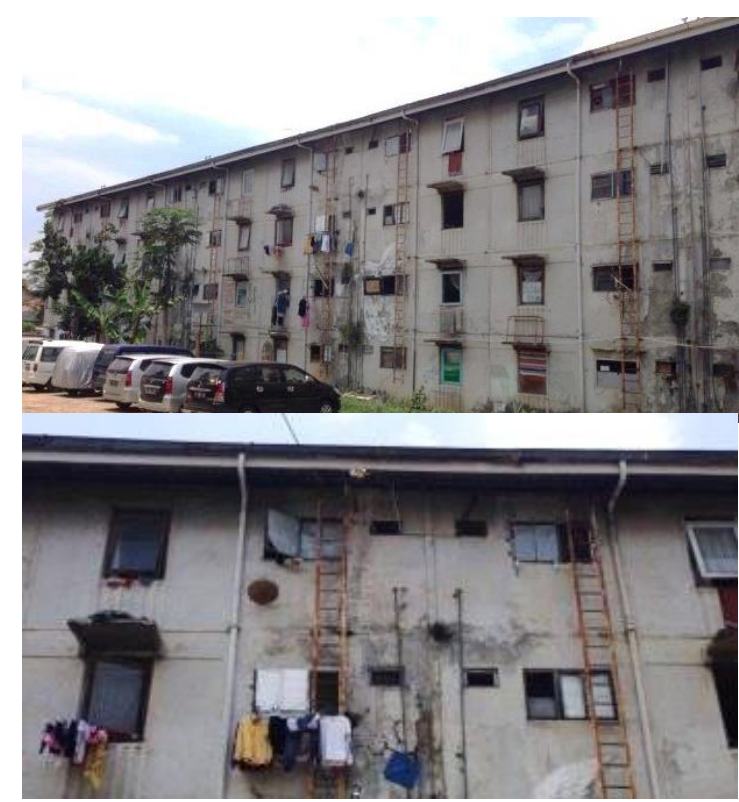

Gambar 1. Rusun Sarijadi Kota Bandung

Setelah dilakukan observasi lapangan ke rusun Sarijadi, terlihat pemandangan yang kurang tertata dan tidak enak dipandang dari jemuran-jemuran penghuni yang di jemur dibagian jendela bangunan rusun, koridor utama dan pada bagian tangga. Potret perilaku menjemur penghuni yang tidak pada tempatnya (Gambar 2). 

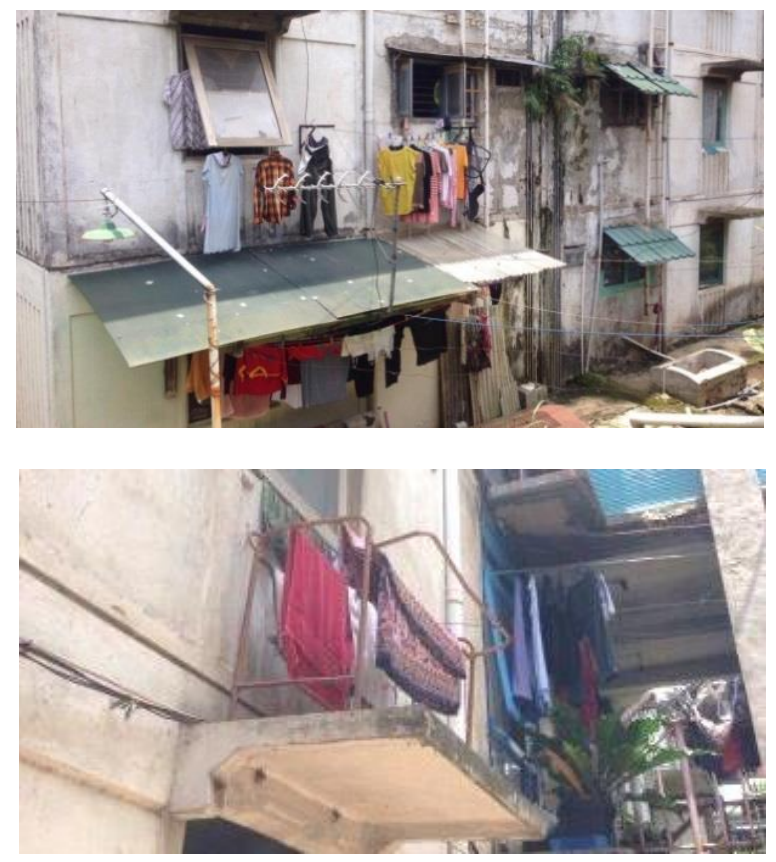

Gambar 2. Potret Perilaku Menjemur Pakaian Penghuni Rusun Sarijadi

Penghuni rusun melakukan pengalihan fungsi ruang yang semestinya bukan sebagai tempat menjemur,

Penghuni melakukan intervensi ruangruang publik sebagai ruang milik pribadi seperti pada tangga dan koridor utama bangunan rusun (Gambar 3).

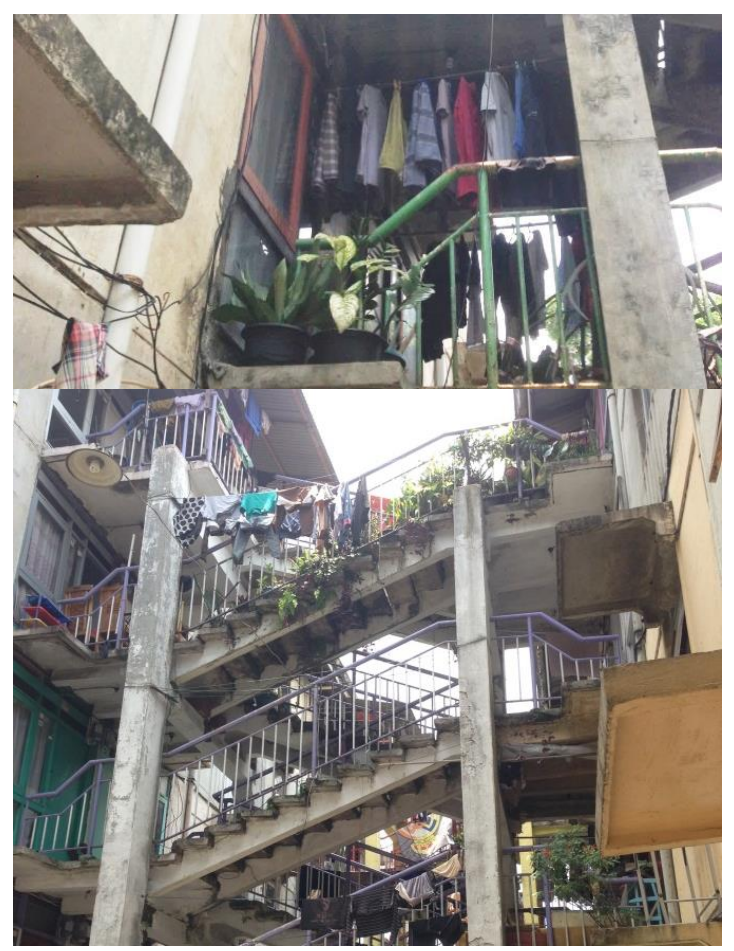

Gambar 3. Penghuni Melakukan Intervensi Ruang Publik Sebagai Ruang Pribadi untuk Aktifitas Menjemur Pakaian
Intervensi ruang publik seperti tangga dan koridor utama menjadi ruang untuk kepentingan pribadi, mengakibatkan munculnya konflik antara penghuni rusun. Konflik yang biasanya terjadi seperti, penghuni satu merasa berkeberatan jika tempat yang diklaim sebagai tempat menjemur pribadinya ditempati oleh penghuni lain, yang pada dasarnya ruang tersebut adalah ruang publik milik seluruh penghuni.

Dari wawancara dengan penghuni rusun, dulunya disediakan satu ruang khusus untuk menjemur pakaian yang terletak disamping dapur di bagian belakang unit hunian, luas ruang menjemur tersebut berkisar $1 \times 1$ meter, karena ukuran ruang menjemur yang dianggap sempit oleh penghuni, membuat penghuni membongkar ruang menjemur tersebut untuk memperluas ruang dapur. Menurut ibu Ujang, para penghuni menganggap kalau fungsi ruang dapur lebih penting daripada ruang untuk menjemur, mereka beranggapan masih bisa menjemur di bagian luar unit hunian yaitu dibagian tangga, koridor dan jendela. Saat rusun tersebut masih baru dikelola terdapat peraturan tertulis untuk larangan penghuninya menjemur dibagian luar gedung, tetapi sekarang peraturan tersebut sudah tidak ada lagi.

Setelah ditanyakan apakah beliau sebagai penghuni merasa terganggu dengan pemandangan jemuran di rusun tempat tinggalnya, beliau mengatakan tidak memiliki pilihan lain karena tidak tersedianya ruang khusus untuk menjemur pakaian sehingga penghuni melakukan pengalihan ruang sebagai tempat menjemur, pada dasarnya penghuni juga menyadari kebiasaan menjemur yang tidak pada tempatnya tersebut membentuk citra yang kurang baik bagi bangunan rusun.

Penghuni yang tinggal dilantai dasar memilih halaman (RTH) di bagian belakang hunian sebagai tempat untuk menjemur (Gambar 4).

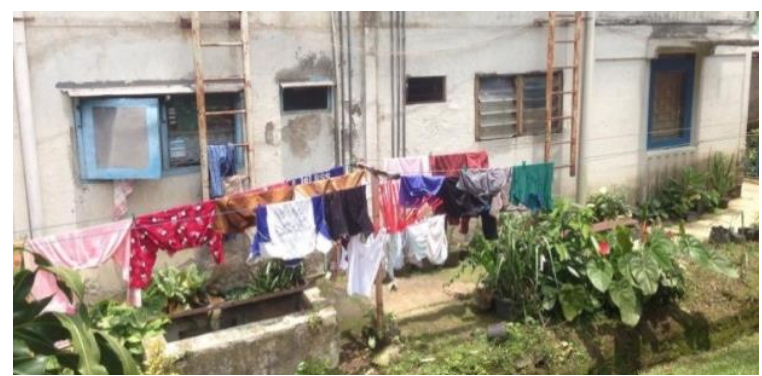

Gambar 4. Perilaku Menjemur Penghuni Rusun Sarijadi 
Wawancara dengan masyarakat penghuni sekitar rusun Sarijadi, dengan Ibu liun. Menurut pandangan beliau terhadap perilaku menjemur pakaian pemukim rusun sarijadi adalah, menambah kesan kumuh dari bangunan tersebut. Menurutnya, bangunan rusun itu sendiri sudah terlihat tidak terawat, ditambah lagi kebiasaan menjemur penghuni yang tidak pada tempatnyamembuat bangunan tersebut terlihat kotor dan tidak tertata, sehingga tidak memberi kesan nyaman dan indah.

\section{HASIL DAN PEMBAHASAN}

Berdasarkan hasil dari observasi dan wawancara, fenomena menjemur pakaian yang tidak pada tempatnya ini disebabkan oleh keterbatasan ruang yang disediakan, hal ini mengakibatkan penghuni tidak dapat memaksimalkan kebutuhan ruangnya sehingga melakukan perubahan fungsi ruang.

Penghuni juga melakukan intervensi ruang - ruang publik sebagai ruang privat untuk menjemur, hal ini disebabkan oleh adaptasi yang dilakukan oleh penghuni. Adaptasi perilaku manusia terhadap pola permukiman horizontal (landed house) menuju pola perumahan vertikal mempengaruhi kondisi sosial psikologis dan perilaku penghuninya. Seperti kecenderungan penghuni untuk mengintervensi zona publik untuk kepentingan pribadi, disini issue arsitektur yakni issue publik/privat muncul (S.Yoseph, 2010).

Adanya perubahan fungsi ruang menjadi tempat menjemur pakaian tersebut membentuk citra yang kurang baik pada bangunan rusun Sarijadi, karena letak tangga, koridor utama dan jendela yang berada dibagian depan bangunan tentunya menjadi pemandangan pertama orang yang melihat bangu-nan rusun tersebut.

Berdasarkan dari teori citra Romo Mangun, citra menunjuk suatu "gambaran" (image), suatu kesan penghayatan yang menangkap arti bagi seseorang. Citra gedung istana yang megah besar tentulah melambangkan kemegahan juga, sedangkan gubug reyot adalah citra yang langsung menggambarkan keadaan penghuni miskin yang serba reyot juga keadaannya. Disini penghuni rusun sendiri memberi kesan yang tidak baik untuk bangunan tempat tinggalnya yang dibentuk oleh kebiasaan menjemur yang tidak pada tepatnya tersebut, mereka sadar telah mengenyampingkan aspek keindahan dan kebersihan pada bangunan tempat tinggalnya. Sama halnya dengan penghuni rusun, masyarakat yang tinggal di sekitar rusun Sarijadi pun memberi kesan yang tidak baik pada bangunan tersebut.

Fenomena menjemur pakaian yang membentuk citra kurang baik dari bangunan rusun ini disebabkan oleh keterbatasan ruang menjemur yang disediakan, sehingga tidak dapat secara maksimal mewadahi aktivitas menjemur penghuninya, karena tidak memiliki pilihan lain, maka penghuni melakukan pengalihan fungsi ruang untuk dapat memenuhi sendiri kebutuhan ruang mereka.

Kurangnya pilihan dari penghuni 'bounded choice' diakibatkan oleh fenomena pemban-gunan rusun yang bersifat seragam "top down", pembangunan dilakukandengan teoriteori hunian vertikal dan tipologi yang sudah ada tanpa dilakukannya studi perilaku dan kebiasaan hidup penghuni terlebih dahulu. Oleh karena itu terjadinya 'bounded choice' dari teori decision making (Savage, 1945 dalam Gigerenzer dan Selten, 2002) pada penghuni. Yaitu kondisi dimana konsumen bersikap 'puas pada kondisi faktual yang minim/rendah (satisfaction with low quality)'yang merupakan bagian dari fenomena 'pilihan hunian yang terbelenggu (bounded choice)' yang diturunkan dari teori rasionalitas yang terbatas 'bounded rationality' (Simon, 1957).

\section{KESIMPULAN}

Pada dasarnya penghuni juga memberi kesan/citra yang kurang baik bagi lingkungan huniannya. Mereka sadar telah mengenyampingkan aspek keindahan dan kebersihan dari perilaku menjemur yang tidak pada tempatnya ini, sehingga membentuk citra yang kurang baik bagi bangunan rusun Sarijadi. Citra kurang baik yang dibentuk oleh perilaku menjemur penghuni ini disebabkan oleh tidak adanya pilihan lain penghuni terhadap huniannya, karena tidak tersedianya ruang menjemur yang cukup untuk mewadahi aktivitas menjemur mereka (Bounded Choice), oleh karenanya penghuni melakukan adaptasi terhadap lingkungan tempat tinggal dengan melakukan pengalihan fungsi ruang. Bounded choice pada penghuni ini disebabkan oleh fenomena pembangunan rusun di Indonesia yang nyaris bersifat seragam top down. 
Untuk perbaikan kedepan agar terciptanya rusun yang memiliki citra yang baik, program pembangunan rusun baiknya dilakukan dengan lebih melihat perilaku dan kebutuhan penghuni terlebih dahulu, dengan lebih melihat perilaku dan pemenuhan kebutuhan penghuni tentunya akan menciptakan kesan/citra yang baik bagi penghuninya sehingga menjadi tolak ukur keberhasilan dari pembangunan sebuah rusun.

\section{Daftar Pustaka}

Gigerenzer, Gerd and Selten, Reinhard. (eds). (2002) Bounded Rationality: The Adaptive Toolbox. London : MIT Press.

Nurdini, A. And Harun, B. Ismet. (2011) Phenomena of Spatial Bounded Choice: Study Related Housing in Bandung as Case Study. Social and Behavioral Sciences 36 (187 - 195)

Mangunwijaya, Y. B. (1988) Wastu Citra. Jakarta : PT. Gramedia

Creswell, J. W. (2003) Research Design. Qualitative, Quantitative, and Mixed Methods Approaches. California: Sage Publications, Inc.

Aryanto, A. Wahid, J. Aulia, D, N. (2005) Kajian Pembentuk Citra Kawasan Perumahan. Studi Kasus: Perumahan Taman Setiabudi Indah, Medan. Jurnal Arsitektur "ATRIUM" vol. 02 no. 02

Bechtel B Robert; Marans W. Robert \&Michelson William (1987) "Methods in Environmental and Behavioral Research". Van Nostrand Reinhold.

Sudrajat, Yoseph. (Agustus, 2010) Adaptasi Perilaku Manusia Terhadap Lingkungan Rumah Susun. Retrivied from: http://ywsarsitek.blogspot.co.id/2010/08/a daptasi-prilaku-manusia-terhadap.html 